\begin{abstract}
Iranica
Abstracta Iranica Revue bibliographique pour le domaine irano-aryen

Volume 37-38-39 | 2018

Comptes rendus des publications de 2014-2016
\end{abstract}

\title{
Anoush Ganjipour. Le réel et la fiction: Essai de poétique comparée
}

Julie Duvigneau

\section{(2) OpenEdition}

\section{Journals}

Édition électronique

URL : http://journals.openedition.org/abstractairanica/43911

DOI : 10.4000/abstractairanica.43911

ISBN : 1961-960X

ISSN : 1961-960X

Éditeur :

CNRS (UMR 7528 Mondes iraniens et indiens), Éditions de l'IFRI

Référence électronique

Julie Duvigneau, «Anoush Ganjipour. Le réel et la fiction : Essai de poétique comparée », Abstracta Iranica

[En ligne], Volume 37-38-39 | 2018, document 1, mis en ligne le 30 décembre 2018, consulté le 02 octobre 2020. URL : http://journals.openedition.org/abstractairanica/43911 ; DOI : https://doi.org/ 10.4000/abstractairanica.43911

Ce document a été généré automatiquement le 2 octobre 2020.

Tous droits réservés 


\title{
Anoush Ganjipour. Le réel et la fiction : Essai de poétique comparée
}

\author{
Julie Duvigneau
}

\section{RÉFÉRENCE}

Anoush Ganjipour. Le réel et la fiction : Essai de poétique comparée. Paris : Hermann, 2014,433 p.

Dans cet ouvrage, qui traverse les frontières entre la philosophie, la littérature et l'historiographie, l'A. propose une réflexion sur la poétique persane et plus particulièrement le rapport entre le réel et la fiction, dans une démarche comparatiste très maîtrisée entre les traditions occidentale et iranienne. Prenant comme point de départ l'opposition entre les interrogations théoriques du "pourquoi la fiction? » du côté de l'Occident et du « pourquoi pas de fiction? » du côté de l'Orient, l'A. établit une relation métaphysique, un schème, entre le réel et la fiction, compliquée par la présence sous-jacente d'un troisième terme du côté de la pensée et de l'art iranien : la vérité, définit comme le « Réel de la réalité ».

Il met ensuite ce schème à l'épreuve d'une lecture attentive des textes. Après avoir examiné l'héritage de Platon, Aristote, Plotin sur cet aspect dans une première partie, il s'intéresse aux apports d'Avicenne, de Sohravardī, de Mollā Sadrā et d'Ibn 'Arabī dans une deuxième.

La troisième partie examine l'éclatement de la temporalité dans la littérature persane en prenant ses deux extrémités : son "commencement dans le genre épique " avec Ferdowsi et « sa fin linguistique » dans le roman, avec Barāheni.

4 La quatrième partie, enfin, s'intéresse à l'historiographie persane à travers trois figures majeures : Baïhaqi, Kasravi et Ādamiat. 
5 L'ouvrage apporte ainsi un éclairage tout en profondeur et en nuances sur la fiction, en proposant en ouverture de reposer la question de la vérité et du besoin que nous en avons.

\section{AUTEURS}

JULIE DUVIGNEAU

INALCO, Mondes iranien et indien, Paris 